\title{
Desain Water Bus Sebagai Sarana Penunjang Pariwisata Di Pulau Biawak Kabupaten Indramayu, Jawa Barat
}

\author{
Riza Ramdhani Djamie, dan Hesty Anita Kurniawati \\ Departemen Teknik Perkapalan, Fakultas Teknologi Kelautan, Institut Teknologi Sepuluh Nopember \\ (ITS) \\ e-mail: tita@na.its.ac.id
}

\begin{abstract}
Abstrak-Kepulauan Biawak terletak di laut jawa di Kabupaten Indramayu Jawa Barat di sebelah utara semenanjung Indramayu seitar 40 kilometer dari pantai utara Indramayu. Pulau biawak adalah salah satu tempat pariwisata yang menarik untuk dikunjungi, daratan seluas 120 hektare kaya akan dengan tanaman bakau, pesona laut yang masih 'perawan', disini terdapat mercusuar juga yang masih berfungsi yang didirikan sejak zaman Belanda dan terdapat juga ikon pulau ini yaitu hewan varanus salvator atau biawak yang sering kita sebut dan wisata lainnya. Sehingga sekarang banyak wisatawan dari daerah luar Kabupaten Indramayu seperti Jakarta, Cirebon dan bahkan luar Jawa Barat yang menuju Pulau Biawak setiap harinya, sehingga sangat sedikit kapal yang melayani para wisatawan. Hal ini menyebabkan berbagai macam persoalan dalam transportasi angkutan wisata, seperti kapal yang tidak terpenuhi, perjalanan yang sangat lama dan kurangnya keselamatan penumpang menuju Pulau Biawak. Oleh sebab itu diperlukan sarana transportasi laut untuk mengatasi permasalahan tersebut, . Pada studi ini dilakukan analisis teknis dan ekonomis dengan menggunakan kapal pembanding yang diperiksa kembali batasan-batasannya sesuai dengan daerah pelayaran yang mempunyai kedalaman rata-rata 2 meter. Berdasarkan analisis yang telah dilakukan didapatkan ukuran optimal bis air, yaitu $L=10.4 \mathrm{~m}, B=4.7 \mathrm{~m}$, $\mathrm{H}=1.2 \mathrm{~m}$ dan $\mathrm{T}=0.3 \mathrm{~m}$. Dari ukuran tersebut kemudian dibuat Lines Plan, General Arrangement dan Safety Plan.
\end{abstract}

Kata kunci-Water Bus, Pulau Biawak, Indramayu.

\section{PENDAHULUAN}

$I^{\mathrm{N}}$ NDONESIA adalah negara yang dua pertiga luas wilayahnya merupakan laut dengan jumlah pulau sekitar 17.500 buah yang hampir seluruhnya dibatasi laut kecuali Pulau Kalimantan yang berbatasan dengan Malaysia, Papua yang berbatasan dengan Papua Nugini, sertadan Nusa Tenggara Timur yang berbatasan dengan Timor Leste. Panjang pantai berdasarkan publikasi yang ada sekitar $81.000 \mathrm{~km}$. Memperhatikan kondisi tersebut, negara Indonesia memiliki sumber daya alam laut yang tidak terhitung besarnya. Dan hampir memiliki 14.664 pulau yang terbesar dari barat hingga ke timur mempunyai karakteristik yang berbeda dan unik. Hal ini dapat di lihat dari lingkungan daratannya dan juga potensi yang ada pada kolam airnya. Biota dan fauna yang terbesar merupakan ekosistem yang unik dan kompleks. Terumbu karang dan mangrove merupakan 2 ekosistem yang mempunyai asosiasi yang sangat banyak dengan lingkungan sekitarnya.

Kabupaten Indramayu terletak di ujung timur laut Jawa Barat pada posisi $107^{\circ} 52^{\prime}-108^{\circ} 36^{\prime}$ Bujur Timur dan $6^{\circ} 14^{\prime}-6^{\circ} 40^{\prime}$ Lintang Selatan. Batas wilayah di sebelah
Barat adalah Kabupaten Subang dan Kabupaten Sumedang, sebelah Utara dengan Laut Jawa, sebelah Timur dengan Laut Jawa dan Kabupaten Cirebon dan sebelah Selatan dengan Kabupaten Cirebon dan Kabupaten Majalengka. Luas wilayah Kabupaten Indramayu 204.000 ha dan memiliki garispantai sepanjang $114 \mathrm{~km}$, yang secara administrative dibagi ke dalam 9 Kecamatan dan 37 Desa pesisir. Dari gambaran tersebut Kabupaten Indramayu memiliki keanekargaman hayati (biodiversity) yang tinggi sehingga mutlak untuk dilindungi, salah satunya sumberdaya alam yang terdapat di gugusan Pulau Biawak.

Pulau biawak ialah salah satu pariwisata yang ada di Kabupaten Indramayuyang terletak di lepas pantai LautJawa, + $40 \mathrm{~km}$ di sebelah Utara pantai Indramayu pada posisi $05^{\circ} 56^{\prime} 002^{\prime \prime}$ LS dan $108^{\circ} 22^{\prime} 015^{\prime \prime}$ BT. Pulau biawak adalah salah satu tempat pariwisata yang menarik untuk dikunjungi, daratan seluas 120 hektare kaya akan dengan tanaman bakau, pesona laut yang masih 'perawan', disini terdapat mercusuar juga yang masih berfungsi yang di dirikan sejak zaman Belanda dan terdapat juga ikon pulau ini yaitu hewan varanus salvator (biawak yang sering kita sebut dan wisata lainnya. Sehingga sekarang banyak masyarakat dari daerah luar Kabupaten Indramayu

Pemerintah disini dituntut untuk tetap hadir menyediakan sarana transportasi laut yang layak, sejauh apapun jaraknya supaya mobilitas akan wisata ke kepulauan tetap berjalan. Selain itu ketersediaan alat transportasi (kapal) laut yang layak menjadi keharusan yang tidak bisa ditunda. Hal ini berlaku juga bagi pemerintah kabupaten Indramayu, namun semua itu akan sia-sia jika faktor keselamatan diabaikan.

Sehingga sekarang banyak wisatawan dari daerah luar Kabupaten Indramayu seperti Jakarta, Cirebon dan bahkan luar Jawa Barat yang menuju Pulau Biawak setiap harinya, sehingga sangat sedikit kapal yang melayani para wisatawan. Hal ini menyebabkan berbagai macam persoalan dalam transportasi angkutan wisata, seperti kapal yang tidak terpenuhi, perjalanan yang sangat lama dan kurangnya keselamatan penumpang menuju Pulau Biawak. Oleh sebab itu diperlukan sarana transportasi laut untuk mengatasi permasalahan tersebut. Sarana transportasi laut tersebut dapat berupa water bus (bis air) yang dapat mengangkut wisatawan yang tidak khawatir akan transportasi yang membawa mereka. Selain itu perencanaan sarana transportasi laut ini diharapkan dapat menambah daya tarik masyarakat Indonesia terhadap bidang kemaritiman dan bidang pariwisata. 


\section{TINJAUAN PUSTAKA}

Bis air merupakan angkutan penumpang dan barang melalui air yang berlayar di sungai-sungai besar, danau maupun laut.

\section{A. Pengertian kapal katamaran}

Katamaran merupakan kapal dengan dua lambung kembar yang dihubungkan dengan struktur bridging. Dengan bentuk badan kapal katamaran yang memiliki dua lambung maka kapal jenis ini memiliki stabilitas yang cukup baik, selain itu luas permukaan kapal yang tercelup air relatif kecil sehingga memiliki sarat yang kecil pula. Katamaran mempunyai garis air lambung yang sangat ramping dengan tujuan untuk memperoleh hambatan yang rendah.
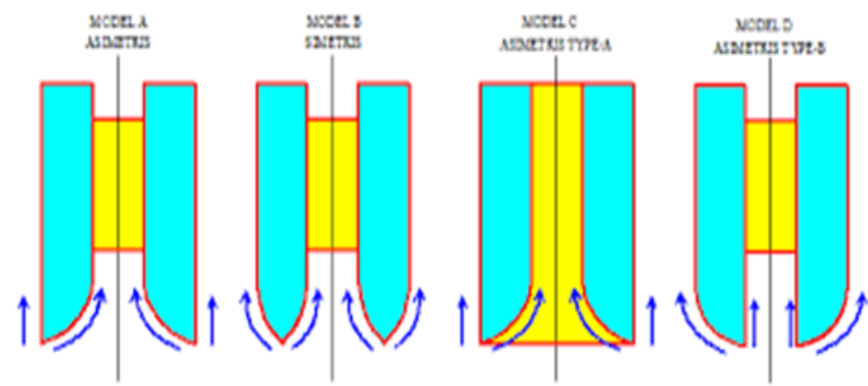

Gambar 1. bentuk lambung kapal katamaran

\section{B. Kondisi Daerah Pelayaran}

Perancangan bis air pada Karya Tulis Ilmiah ini berlayar menyusuri pantai utara pulau Jawa dari Probolinggo hingga Surabaya dengan jarak tempuh $\pm 99,4 \mathrm{~km}$. Karekteristik peraian daerah ini antara lain: kedalaman perairan berkisar 2-25 m, tinggi gelombang sebesar $0.5 \mathrm{~m}$, perbedaan pasangsurut sebesar $3.1 \mathrm{~m}$ dengan jarak dari garis pantai $\pm 1.5 \mathrm{~km}$, kecepatan angin di atas permukaan laut pada musim barat mencapai 35 knot dengan frekuensi $28.57 \%$, sedangkan pada musim timur mencapai 27 knot dengan frekuensi $32.55 \%$ dan kecepatan arus maksimal \pm 2 mil/jam.

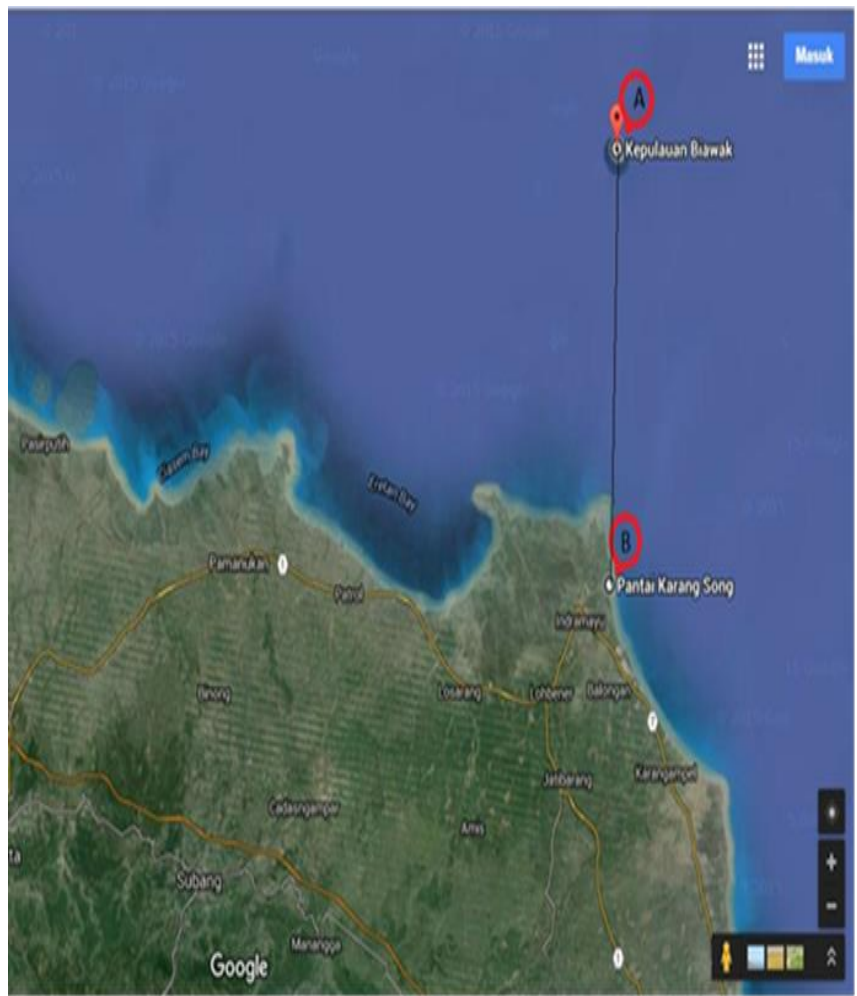

Gambar 2. Rute Pelayaran Bis Air (Sumber: www.googlemap.com, 2015)

\section{METODOLOGI PENELITIAN}

Metodologi penelitian yang digunakan dalam Karya Tulis Ilmiah ini adalah sebagai berikut:

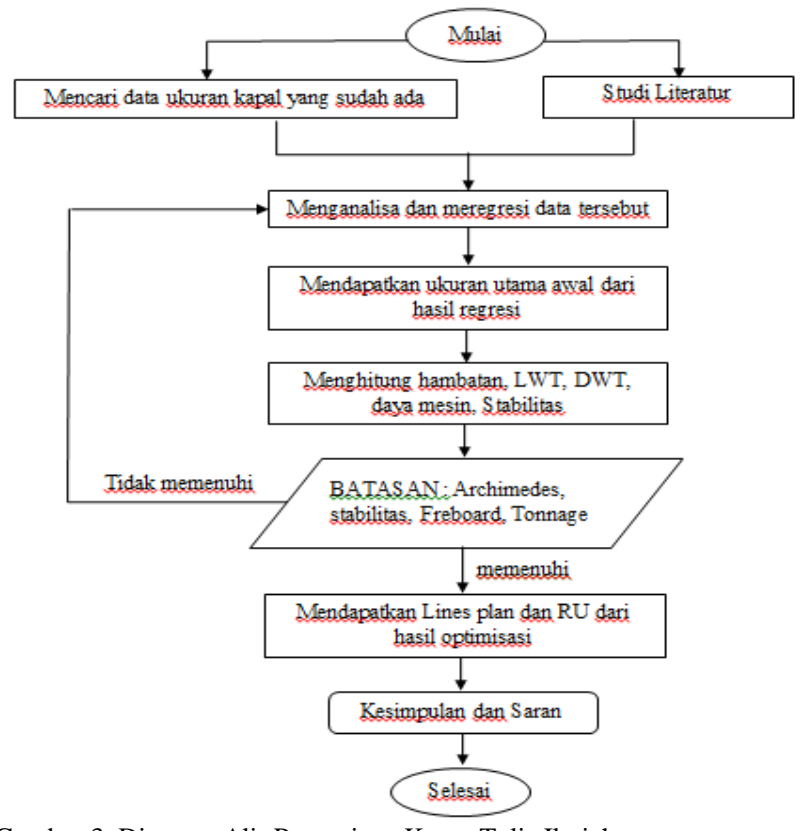

Gambar 3. Diagram Alir Pengerjaan Karya Tulis Ilmiah

\section{ANALISIS TEKNIS}

\section{A. Penentuan Payload dan jumlah Trip}

Langkah pertama dalam proses desain kapal adalah merencanakan owner's requirements, salah satunya adalah payload, atau muatan yang diangkut oleh kapal. Dalam hal ini, muatan yang dimaksud adalah jumlah penumpang. Maka dari itu dibutuhkan data awal untuk merencanakan muatan kapal, yaitu jumlah penumpang yang akan berkunjung ke Pulau Biawak. Kurangnya informasi tentang jumlah pengunjung dari Badan Pusat Statistik menjadikan alasan untuk pengambilan keputusan tentang jumlah penumpang kapal ditentukan dari pengalaman nelayan yang biasa kapalnya di sewakan wisatawan menuju Pulau Biawak yang pernah berkunjung kesana dan dari Kepala Seksi Dinas Pariwisata Kabupaten Indramayu.

Dari sumber yang didapatkan melalui wawancara langsung dengan beberapa nelayan di Karangsong, jumlah wisatawan yang berkunjung ke Pulau Biawak sehari harinya biasanya hanya berkisar 10-15 orang, dengan asumsi penambahan 5 orang setiap harinya.namun pada musim liburan wisatawan yang berkunjung bisa mencapai lebih dari 30-40 orang. Kemudian untuk penginapan di Pulau Biawak, banyak homestay yang menyediakan. Biasanya satu homestay dapat menampung 6-10 orang, tapi karena keramahan penduduk untuk penginapan akan banyak homestay dadakan yang ada di Pulau Biawak.

Jumlah Trip hanya 1 kali perjalanan jam keberangkatan pukul 04.00 pagi dan waktu kembali ke daratan pukul 16.00. Langkah pertama dalam proses desain kapal adalah merencanakan owner's requirements, salah satunya adalah payload, atau muatan yang diangkut oleh kapal. Dalam hal ini, muatan yang dimaksud adalah jumlah penumpang. Maka dari itu dibutuhkan data awal untuk merencanakan muatan kapal, yaitu jumlah penumpang yang akan berkunjung ke Pulau Biawak. Kurangnya informasi tentang jumlah pengunjung dari Badan Pusat Statistik menjadikan alasan untuk pengambilan keputusan tentang jumlah 
penumpang kapal ditentukan dari pengalaman nelayan yang biasa kapalnya di sewakan wisatawan menuju Pulau Biawak yang pernah berkunjung

\section{B. Kecepatan Bis Air}

Waktu perjalanan bis air $=2$ jam (di asumsikan lebih cepat dari pada perahu nelayan yang memakan waktu 4 jam).

Jarak Probolinggo hingga Surabaya $=40 \mathrm{~km}$.

Kecepatan yang dibutuhkan untuk memenuhi waktu tersebut $=\underline{40 \mathrm{~km}}$

$$
\begin{aligned}
& \frac{4 \mathrm{jam}}{=} \\
= & 20 \mathrm{~km} / \mathrm{jam} \div 1,852 \\
= & 10,799 \mathrm{knot}=11 \mathrm{knot}
\end{aligned}
$$

\section{Penentuan Ukuran Utama Bis Air}

Penentuan ukuran utama bis air untuk rute KarangsongPulau Biawak ini mengacu pada dimensi kapal-kapal yang sudah ada dengan mempertimbangkan kondisi daerah pelayaran dan kebutuhan ruangnya agar bis air dapat melakukan manuver dengan baik. Berikut data kapal pembandingnya:

Tabel 1.

Data Kapal Pembanding

\begin{tabular}{|c|c|c|c|c|c|c|}
\hline no & nama kapal & kapasitas orang & L & B & H & T \\
\hline 1 & Solarwave 46 & 25 & 11 & 7 & 1,6 & 0,6 \\
\hline 2 & Athena 38 & 20 & 11,6 & 6,3 & 1,3 & 0,7 \\
\hline 3 & Bata Graine & 12 & 9,7 & 4 & 1,6 & 0,6 \\
\hline 4 & SUNCAT 46 & 30 & 14 & 9,1 & 1,8 & 1,2 \\
\hline 5 & Lagoon 380 4C & 20 & 11,5 & 6,63 & 1,6 & 1 \\
\hline 6 & Mahe 36 & 23 & 11 & 6 & 1,7 & 0,9 \\
\hline 7 & Lavezzi 40 & 17 & 10 & 6,5 & 1 & 0,8 \\
\hline 8 & Catana 42 OC & 18 & 12,58 & 6,86 & 1,8 & 0,6 \\
\hline 9 & Lipari 41 & 19 & 11,95 & 6,7 & 1,1 & 0,6 \\
\hline 10 & catamaran HA1245 & 24 & 12,45 & 5,5 & 1,5 & 0,7 \\
\hline 11 & Ecosol 34 & 20 & 11,5 & 6 & 1,4 & 0,7 \\
\hline 12 & Passenger Ferry & 12 & 8,76 & 4 & 1 & 0,4 \\
\hline 13 & Ecocast & 10 & 7 & 4,5 & 0,8 & 0,3 \\
\hline 14 & Tema 360Cat & 19 & 13,74 & 7 & 1,7 & 0,6 \\
\hline 15 & Cat Taxi & 12 & 9,8 & 5 & 1 & 0,3 \\
\hline
\end{tabular}

Ukuran utama kapal optimal sesuai dengan pemeriksaan yang telah dilakukan dalam Studi ini, sebagai berikut:
$\mathrm{L}=10,423 \mathrm{~m}$
$\mathrm{T}=0,381 \mathrm{~m}$
$\mathrm{BT}=4,738 \mathrm{~m}$
$\mathrm{S}=2,520 \mathrm{~m}$
$\mathrm{H}=1,298 \mathrm{~m}$
$\mathrm{B}=1,109 \mathrm{~m}$

Berikut ini layout awal dari ukuran utama yang optimal:

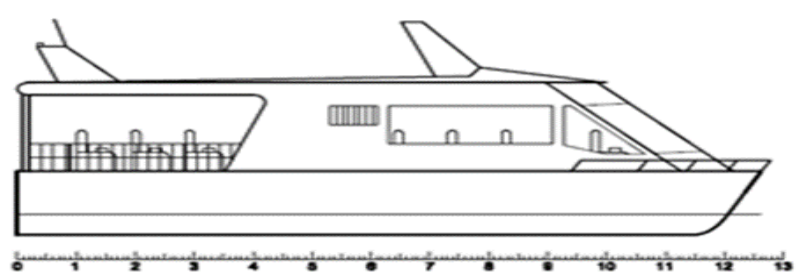

MAIN DECK

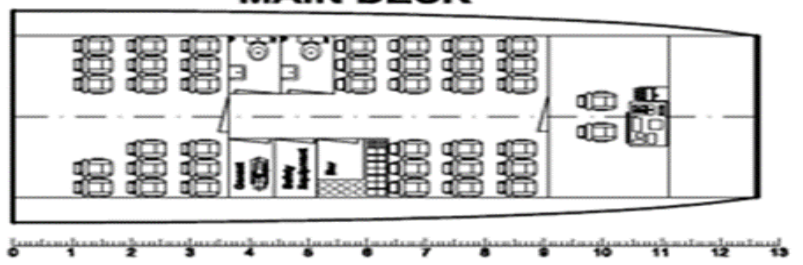

TANK TOP

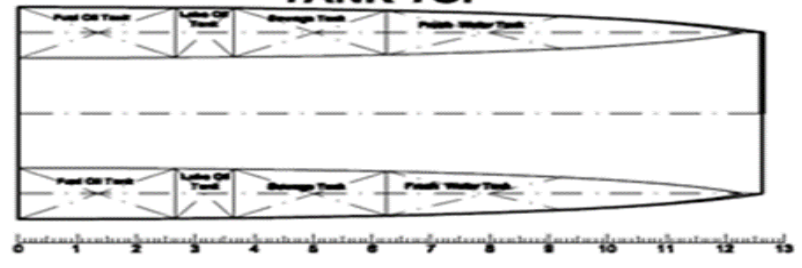

Gambar 4. Layout Awal Bis Air

\section{Perhitungan Displacement dan Koefisien}

- Froude Number dapat dihitung dengan rumus sebagai berikut: $\mathrm{Fn}=\mathrm{Vs} / \sqrt{\mathrm{g} \cdot \mathrm{L}}$

Didapatkan nilai $\mathrm{Fn}=0,559$

- $\quad$ Volume Displacement ( $\nabla)$

$\nabla=3.902 \mathrm{~m}^{3}$

$\nabla=7.805 \mathrm{~m}^{3}$ untuk dua buah lambung

- Displacement $(\Delta)$

$\Delta=\nabla \mathrm{t} \times \rho_{\text {air }} \quad$ (ton)

$\Delta=7.805 \times 1.025$

$\Delta=8.0001$ ton

- Block Coefficient (Cb)

$\mathrm{Cb}=\Delta /($ L.B.T. $\rho)$

$\mathrm{Cb}=0.886$

- $\quad$ Midship Coefficient (Cm)

$\mathrm{Cm}=1,006-0,0056 \mathrm{Cb}^{-3,56}$

$\mathrm{Cm}=1.044$

- Prismatic Coefficient (Cp)

$\mathrm{Cp}=\mathrm{Cb} / \mathrm{Cm}$

$\mathrm{Cp}=0.516$

- Waterplan Coefficient (Cwp)

$\mathrm{Cwp}=\mathrm{Cb} /(0,471+0,551 \mathrm{Cb})$

$\mathrm{Cwp}=0.650$

\section{E. Perhitungan Hambatan Bis Air}

Perhitungan hambatan kapal katamaran dengan menggunakan rumus yang didapat dari paper Insell \& Molland, yang terdiri dari beberapa komponen antara lain:

$\begin{array}{ll}\text { - }(1+\beta \mathrm{k}) & =1.469 \\ \text { - } \mathrm{C}_{\mathrm{F}} & =2.312 \times 10^{-3} \\ \text { - } \tau & =1.638 \\ \text { - } \mathrm{C}_{\mathrm{w}} & =0.0043\end{array}$

Nilai dari masing-masing komponen diatas didapat dari interpolasi. Setelah didapatkan nilai dari masing-masing komponen langkah selanjutnya yaitu menghitung koefisien hambtan total dengan menggunakan rumus:

$C_{\text {Tot }}=(1+\beta k)^{*} C_{F}+\tau C_{W}$ 
$C_{\text {Tot }}=1.058 \times 10^{-2}$

Setelah nilai koefisien hambatan didapatkan, maka hambatan bis air dapat dihitung dengan menggunakan rumus:

$\mathrm{R}_{\mathrm{T}}=0,5 \times \rho \times 2 \times \mathrm{WSA} \times \mathrm{V}^{2} \times \mathrm{C}_{\mathrm{Tot}}$

Dengan nilai WSA sebesar $25,678 \mathrm{~m}^{2}$. Maka hambtan bis air:

$$
\begin{aligned}
& \mathrm{R}_{\mathrm{T}}=4461.1843 \mathrm{~N} \\
& \mathrm{R}_{\mathrm{T}}=4.46 \mathrm{kN} \\
& \mathrm{R}_{\mathrm{T}}+15 \% \text { Margin }=4.61 \mathrm{kN}
\end{aligned}
$$

\section{F. Perhitungan Power dan Pemilihan Mesin Induk}

Dari pehitungan yang dilakukan didapatkan nilai BHP sebesar 72.11 HP. Setelah didapat nilai BHP maka langkah selanjutnya yaitu memilih mesin sebagai penggerak utama kapal. Mesin induk yang dipakai pada kapal katamaran ini adalah mesin outboard merk Mercury.

\section{G. Perhitungan Berat Kapal}

\section{- $\quad$ DWT (Dead Weight Tonnage)}

Tabel 2.

Perhitungan Komponen Berat Kapal Bagian DWT

\begin{tabular}{|c|l|c|c|}
\hline \multicolumn{3}{|c|}{ Total Berat BagianDWT } \\
\hline No & Komponen Berat Kapal Bagian DWT & Value & Unit \\
\hline 1 & Berat Penumpang dan Barang Bawaan & 1,440 & ton \\
\hline 2 & Berat Crew dan Barang Bawaan & 0,16 & ton \\
\hline 3 & Berat Fresh Water & 0,200 & ton \\
\hline 4 & Berat Fuel Oil & 0,0287 & ton \\
\hline 5 & Berat Lubrication Oil & 0,000078 & ton \\
\hline \multicolumn{2}{|c|}{ Total } & $\mathbf{1 , 8 2 9}$ & ton \\
\hline
\end{tabular}

- $\quad$ LWT (Light Weight Tonnage)

\begin{tabular}{|c|c|c|c|}
\hline \multicolumn{4}{|c|}{ Total Berat Bagian LWT } \\
\hline No & Komponen Berat Kapal Bagian LWT & Value & Unit \\
\hline 1 & Berat Lambung Kapal & 3,340 & ton \\
\hline 2 & Berat Geladak Kapal & 2,752 & ton \\
\hline 3 & Berat Konstruksi Kapal & 1,218 & ton \\
\hline 4 & Berat Dinding Kapal & 1,0844 & ton \\
\hline 5 & Berat Atap Kapal & 1,1877 & ton \\
\hline 6 & Berat Kaca Polycarbonated & 0,0344 & ton \\
\hline 7 & Berat Outboard Motor & 0,326 & ton \\
\hline 8 & Berat Peralatan dan Perlengkapan & 1,777 & ton \\
\hline 9 & Berat Kamar Mandi & 0,056 & ton \\
\hline 10 & Berat Ruang Penumpang & 0,140 & ton \\
\hline 11 & Berat Ruang Navigasi & 0,111 & ton \\
\hline \multicolumn{2}{|r|}{ Total } & 12,026 & ton \\
\hline
\end{tabular}

Tabel 3.

Perhitungan Komponen Berat Kapal Bagian LWT

Total berat DWT+LWT $=1.829+12.026=13.855$ ton.

\section{H. Pemeriksaan Teknis}

\section{- Freeboard}

Freeboard perhitungan $=0.45 \mathrm{~m}$

Actual freeboard $\quad=0.917 \mathrm{~m}$

Kriteria: Actual freeboard lebih besar dari freeboard perhitungan sehingga (Memenuhi)

- Stabilitas

\begin{tabular}{|c|c|c|}
\hline $\mathrm{e} 30^{\circ} \geq 0.055$ & $=14,837$ & (Memenuhi) \\
\hline $\mathrm{e} 40^{\circ} \geq 0.09$ & $=23,594$ & (Memenuhi) \\
\hline $\mathrm{e} 30^{\circ}-40^{\circ} \geq 0.03$ & $=1,952$ & (Memenuhi) \\
\hline $\mathrm{GZ} 30^{\circ} \geq 0.055$ & $=2,060$ & (Memenuhi) \\
\hline$\theta \max \geq 25^{\circ}$ & $=85$ & (Memenuhi) \\
\hline $\mathrm{GM} 0 \geq 0.15$ & $=4,048$ & (Memenuhi) \\
\hline
\end{tabular}

Kriteria: (sumber: IMO International Code on Intact

Stability, 2008)

\section{ANALISIS EKONOMIS}

Dari analisis ekonomis yang sudah dilakukan, didapatkan hasil sebagai berikut:

- Harga Pokok Produksi

$=$ Rp. 1.513.150.672,29

- Harga Jual Kapal

$=$ Rp. $1.770 .386 .286,70$

- Nilai NPV

- Nilai BEP

- Angsuran per tahun

= Rp. 1.174.192.335,96

$=5$ tahun

= Rp. $321 \cdot 629 \cdot 215,86$

- Jumlah bunga total

$=$ Rp. $96.488 .764,76$

\section{HASIL DESAIN DALAM BETUK GAMBAR}

Setelah diketahui ukuran utama optimal yang didapat dari analisis teknis, kita dapat membuat gambar Lines Plan, Rencana Umum, bentuk 3 Dimensi dan Safety Plan dari Bis Air yang ditunjukkan dalam gambar $6.1,6.2,6.3$ dan 6.4 berikut ini:

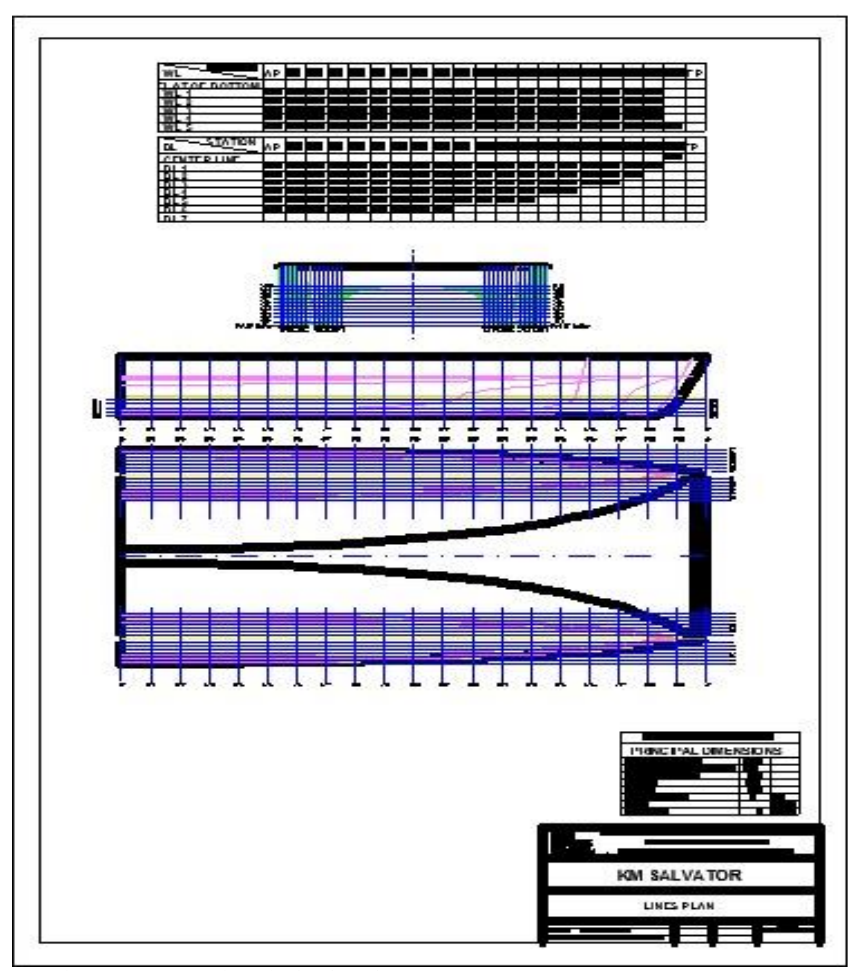

Gambar 5. Lines Plan dari Bis Air 


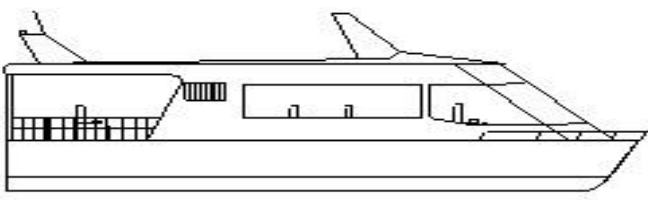

MAIN DECK
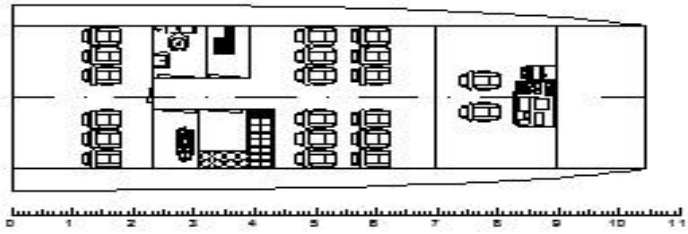

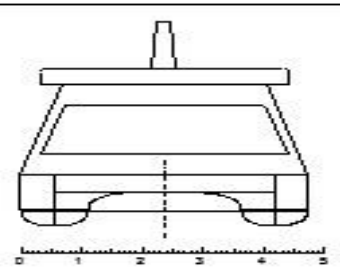

TANK TOP

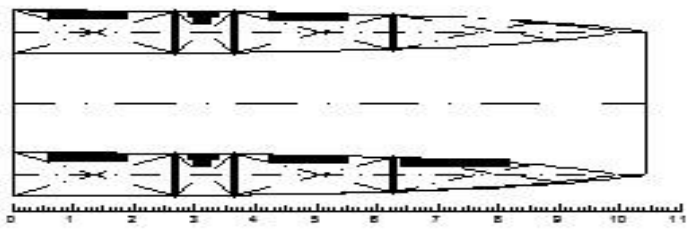

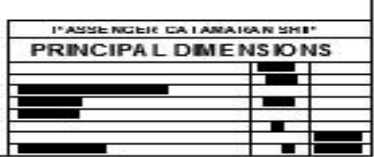

Gambar 6. Rencana Umum dari Bis Air

Seperti terlihat pada gambar rencana umum diatas, bahwa bis air dalam Karya Tulis Ilmiah ini memiliki 3 ruangan utama, yaitu ruang navigasi, ruang penumpang dalam dan ruang penumpang luar. Ruang navigasi merupakan ruangan yang digunakan oleh nahkoda dan crew untuk mengemudikan bis air, didalam ruangan ini terdapat berbagai macam alat-alat navigasi seperti radio, kompas, radar, GPS, dan lain-lain. Ruang penumpang dalam merupakan ruangan yang digunakan untuk penumpang yang lebih menginginkan kenyamanan selama pelayaran, didalam ruangan ini juga terdapat bar yang menawarkan makananmakanan ringan dan minuman untuk para penumpang, selain itu juga terdapat dua buah toilet yang dapat digunakan untuk semua penumpang dan crew. Ruang penumpang luar merupakan ruangan yang digunakan untuk penumpang yang ingin menikmati pemandangan alam sekitar daerah pelayaran.
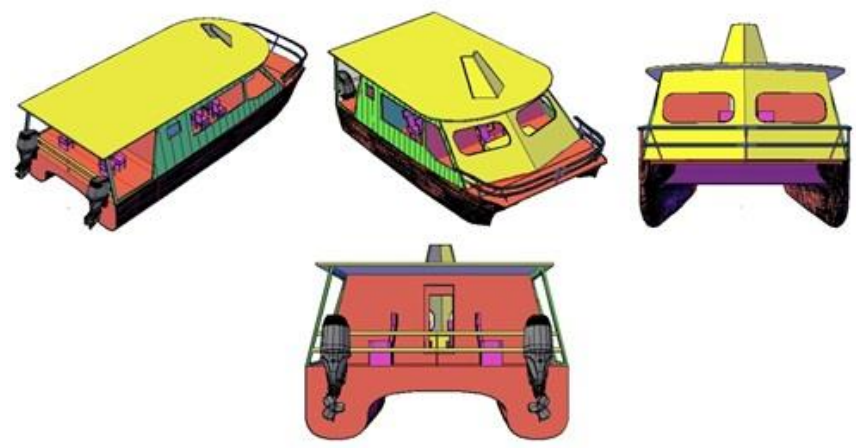

Gambar 7. Bentuk 3 Dimensi dari Bis Air

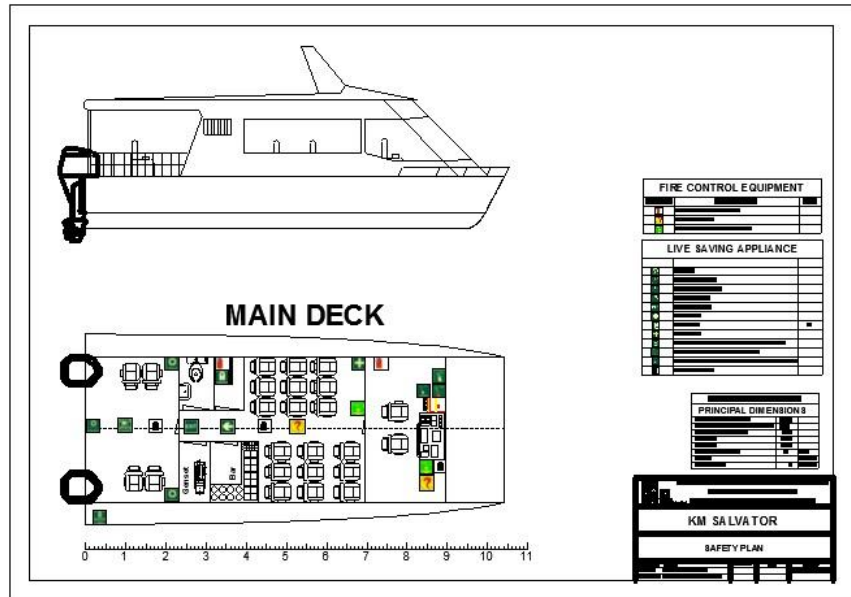

Gambar 8. Safety Plan dari Bis Air

\section{KESIMPULAN}

Dari analisis teknis dan ekonomis yang sudah dilakukan, dapat ditarik kesimpulan sebagai berikut:

1. Ukuran utama optimal yang didapat adalah $\mathrm{Lwl}=12,06$ $\mathrm{m}, \mathrm{Lpp}=10,42 \mathrm{~m}, \mathrm{~B}=4,73 \mathrm{~m}, \mathrm{H}=1,29 \mathrm{~m}, \mathrm{~T}=0,38 \mathrm{~m}$, $\mathrm{S}=2,52 \mathrm{~m}$.

2. Biaya pembangunan sebesar Rp. 1.513.150.672,39 dan harga jual sebesar Rp. 1.770.386.286,70.

\section{DAFTAR PUSTAKA}

[1] Bandung.Bisnis.com. (2014). Kunjungan Wisatawan Asing ke Indramayu Naik 12,2\%. Retrieved September 01, 2015, form web site : http//www.bandungbisnis.com.

[2] Billah, A. (2014). Transportasi dan Wisata Rute Probolinggo Surabaya, Studi, Jurusan Teknik Perkapalan, FTK, ITS

[3] Biro Klasifikasi Indonesia. 2006. Rules for The Classification and Construction of Seagoing Steel Ships, Volume II, Rules for Hull. Jakarta : Biro Klasifikasi Indonesia.

[4] Direktori Wisata. (2013). Pulau Biawak Eksostisme Indramayu. Retrieved September 01, 2015, from Direktori Wisata web site: http//disparbud.jabarprov.go.id 
[5] IMO. (2002). International Convention of Load Lines 1996 and Protocol 1988. International Maritime Organization..

[6] Insel, M. \& Molland, A. F. (1992). An Investigation Into The Resistance Components of High Speed Displacement Catamarans. London: RINA.

[7] Parsons, M. G. (2001). Parametric Design, Chapter 11. USA Department of Naval Architecture and Marine Engineering, University of Michigan

[8] Pramoko, A. G. (2013). Studi Perancangan Trash-Skimmer Boat di Perairan Teluk Jakarta. Studi, Jurusan Teknik Perkapalan, FTK, ITS.

[9] Riany. (2013). Trip to Pulau Biawak Indramayu. Retrieved September 01, 2015, from web site http://rianytam.wordpress.com/2013/03/ Trip to Pulau Biawak Indramayu.html
[10] Rakyatnusantara.com. (2015). Kapal Tenggelam, 2 Wisatawan Pulau Biawak Indramayu Tewas. Retrieved September01,2015,formwebsite:http//www.Rakyatnusantara.com.

[11] Sahaya. (2010). Pulau Biawak, Atol Di Laut Jawa II; Teknis Perjalanan. Retrieved September 01, 2015, from web site http://lembaranpung.wordpress.com/2010/07/ Pulau Biawak, Atol Di Laut Jawa II; Teknis Perjalanan.html

[12] Santosa, I. G. (1999). Diktat Kuliah. Perancangan Kapal II. Surabaya: Institut Teknologi Sepuluh Nopember.

[13] Taggart, Robert. Ed. 1980. Ship Design and Construction.The Society of Naval Architects and Marine Engineers.

[14] Virliani, P. (2007). Perencanaan Bis Air sebagai sarana transportasi angkutan penumpang di aliran banjir kanal barat Jakarta, Studi, Jurusan Teknik Perkapalan, FTK, ITS

[15] Mercurymarine.com/en/nz/engines/outboard/. 